\title{
Synergistic Therapy for Cervical Cancer by Codelivery of Cisplatin and JQ1 Inhibiting Plk1-Mutant Trp53 Axis
}

Yinan Wang ${ }^{\dagger}$, Na Shen ${ }^{*}$, Shuchun Li ${ }^{\S}$, Haiyang Yu* Yue Wang*, Zhilin Liu ${ }^{\ddagger}$, Liying Han $^{* *}$ and Zhaohui Tang**

$\dagger$ The Department of Obstetrics and Gynecology, The Second Hospital of Jilin University, Changchun 130022, PR China

$\star$ Key Laboratory of Polymer Ecomaterials, Changchun Institute of Applied Chemistry, Chinese Academy of Sciences, Changchun 130022, PR China

$\S$ The Department of Pain, The Second Hospital of Jilin University, Changchun 130022, PR China

Corresponding author:

*Email for N.S.: nshen@ciac.ac.cn, Tel: 86-431-85262518, Fax: 86-431-85262116.

*Email for L.H.: hanly@jlu.edu.cn, Tel: 86-431-81136726, Fax: 86-431-81136590.

*Email for Z.T.: ztang@ciac.ac.cn, Tel: 86-431-85262449, Fax: 86-431-85262116.

Materials. Methoxy poly (ethylene glycol)-b-poly (L-glutamic acid- $c o-\mathrm{L}-$ phenylalanine $)$, named $\mathrm{mPEG}_{113}-b-\mathrm{P}\left(\mathrm{Glu}_{10}-c o-\mathrm{Phe}_{10}\right)$ and abbreviated as 
PGP, was prepared as previously described ${ }^{1}$. JQ1 was purchased from the Jilin Chinese Academy of Sciences-Yanshen Technology Co. Ltd (Jilin, China). Dulbecco's modified Eagle's medium (DMEM) and fetal bovine serum (FBS) were purchased from Gibco BRL Life Technology (Grand Island, NY, USA). Penicillin and streptomycin were purchased from Huabei Pharmaceutical Co. Ltd. (Shijiazhuang, China). Cell Counting Kit-8 (CCK-8) was purchased from Dojindo Chemical Technology Co. Ltd. (Shanghai, China). Annexin V-FITC apoptosis detection kit was purchased from Shanghai Beyotime Biotechnology Co. LTD. Purified deionized water was prepared using the Milli-Q plus system (Millipore Co., Billerica, MA, USA). The mRNA was extracted using the RNA Extraction Kit (centrifugal column type, Biotetk, Wuxi, China). The cDNA was prepared by reverse transcription from total RNA (NovoScript 1st strand cDNA Synthesis SuperMix kit; Shanghai, China). qPCR was performed using SYBR Green qPCR Master Mix (Thermo Fisher Scientific, Rockford, IL, USA). Protein concentration was determined using the BCA assay kit (Thermo Scientific, Rockford, IL, USA). Cell transfection of siRNA was performed using the GoldenTran-R siRNA transfection kit (Golden Trans Technology, Changchun, China).

Characterization. ${ }^{1} \mathrm{H}$ NMR spectra were characterized by Bruker AV-500 or Bruker AV-300 NMR spectrometer. The zeta potential of nanoparticles was measured using a Zeta PALS (Brookhaven Instruments Corporation, New York, USA). The size of the self-assembled nanoparticles was evaluated by Dynamic light scattering. Gel permeation chromatography (GPC) measurements were performed on a waters GPC 
system (Waters Ultrahydrogel Linear column). Inductively coupled plasma mass spectrometry (ICP-MS, NexION 1000G, PerkinElmer, USA) was used for the quantitative determination of platinum levels. JQ1 release was calculated by high performance liquid chromatography (HPLC), which was composed of a Waters 2414 Refractive Index Detector, a Waters 515 HPLC pump and a reverse-phase C-18 column (Symmetry®). Flow cytometry analysis was carried out by a flow cytometer (BD FACS Canto II, Becton, Dickinson and Company, Franklin Lakes, USA). Histological alterations were evaluated under the optical microscope (Nikon Eclipse Ti, Optical Apparatus Co. Ardmore, PA, USA). All the siRNA transfection samples were imaged using a laser confocal microscope (Olympus Corporation, Tokyo, Japan).

Synthesis of PGP copolymers. PGP copolymer was synthesized according to previous report ${ }^{1}$. In brief, $\mathrm{mPEG}_{113}-\mathrm{NH}_{2}$ was dissolved in dry N,N-Dimethylformamide (DMF) after an azeotropic dehydration process with toluene, then Phe-NCA and BLG-NCA dissolved in dry DMF were added via a syringe under argon. The reaction was maintained for 3 days at $35^{\circ} \mathrm{C}$ under argon. Then, methoxy poly(ethylene glycol $)_{113}$ - $b$-poly $\left(\gamma\right.$-benzyl-L-glutamate $10-c o$-L-phenylalanine $\left.{ }_{10}\right)$ $\left(\mathrm{mPEG}_{113}-b-\mathrm{P}\left(\mathrm{BLG}_{10}-c o-\mathrm{Phe}_{10}\right)\right)$ block copolymer was isolated by repeated precipitation from DMF into an excess amount of ice cold diethyl ether. Subsequently, $\mathrm{mPEG}_{113}-b-\mathrm{P}\left(\mathrm{BLG}_{10}-c o-\mathrm{Phe}_{10}\right)$ was dissolved in dichloroacetic acid. After HBr/acetic acid (33 wt \%) was added, the solution was maintained at $25^{\circ} \mathrm{C}$ under stirring for $1 \mathrm{~h}$. Then the crude product was obtained by precipitation into excessive ice cold diethyl 
ether. After being dried under vacuum, the crude product was dialyzed (MWCO 3500 Da) against distilled water and lyophilized to give the $\mathrm{PPEG}_{113}-b-\mathrm{P}\left(\mathrm{Glu}_{10}-c o-\mathrm{Phe}_{10}\right)$ product, yielding a white solid. The structure was determined by ${ }^{1} \mathrm{H}$ NMR using trifluoroacetic acid-d as the solvent, molecular weight distributions of the PGP copolymers were determined by GPC.

Synthesis of the nanomedicines. PGP was dissolved in $400 \mathrm{~mL}$ distilled water, then JQ1 dissolved in DMF and cisplatin (CDDP) dissolved in distilled water were respectively added dropwise to the PGP solution, according to a fixed feeding ratio. After $72 \mathrm{~h}$ of reaction at $37^{\circ} \mathrm{C}$, the solution was dialyzed for $24 \mathrm{~h}$ using a dialysis bag (MWCO $3500 \mathrm{Da}$ ), and then freeze-dried to obtain PGP-CDDP/JQ1. The synthesis method of PGP-CDDP and PGP-JQ1 were similar to this method. PGP was dissolved in distilled water $(400 \mathrm{~mL})$, then JQ1 dissolved in DMF or CDDP dissolved in distilled water were added dropwise to the PGP solution. After $72 \mathrm{~h}$ of reaction at 37 ${ }^{\circ} \mathrm{C}$, the solutions were dialyzed for $24 \mathrm{~h}$ using a dialysis bag (MWCO $3500 \mathrm{Da}$ ), and then freeze-dried to obtain PGP-JQ1 or PGP-CDDP. All the nanomedicines were stored at $-20{ }^{\circ} \mathrm{C}$. The loading content of CDDP and JQ1 in the nanomedicines was determined by ICP. The drug loading content (DLC) and drug loading efficiency (DLE) were calculated as follows:

DLC $(\%)=\frac{\text { weight of drug in micelles }}{\text { weight of drug-loaded micelles }} \times 100 \%$

DLE $(\%)=\frac{\text { weight of drug in micelles }}{\text { total weight of drug for loading }} \times 100 \%$ 
In vitro JQ1 release. PGP-JQ1 and PGP-CDDP/JQ1 (containing $0.5 \mathrm{mg} \mathrm{JQ1,}$ dissolved in $5 \mathrm{~mL}$ buffer) were respectively added to a dialysis bag (MW 3,500 Da), and then immersed in $45 \mathrm{~mL}$ buffer under shaking $(90 \mathrm{rpm})$ at $37{ }^{\circ} \mathrm{C}$ at two separate conditions: $10 \mathrm{mM}$ phosphate buffered saline (PBS) pH 7.4 and $10 \mathrm{mM}$ PBS pH 6.8. At each desired time point ( $1 \mathrm{~h}, 3 \mathrm{~h}, 6 \mathrm{~h}, 10 \mathrm{~h}, 24 \mathrm{~h}, 48 \mathrm{~h}, 72 \mathrm{~h}, 96 \mathrm{~h}), 5.0 \mathrm{~mL}$ of the release solution was withdrawn and $5.0 \mathrm{~mL}$ of the same fresh buffer was replaced in the PGP-CDDP/JQ1 group, while at each desired time point $(1 \mathrm{~h}, 3 \mathrm{~h}, 10 \mathrm{~h}, 24 \mathrm{~h}, 48 \mathrm{~h}$, $72 \mathrm{~h}, 96 \mathrm{~h}$ ), $5.0 \mathrm{~mL}$ of the release solution was withdrawn and $5.0 \mathrm{~mL}$ of the same fresh buffer was replaced in the PGP-JQ1 group. The release test was repeated in triplicate under the same conditions. The amount of released JQ1 was measured by HPLC. The HPLC system consisted of a reverse-phase C-18 column (Symmetry), and a mobile phase of acetonitrile and water $(80: 20 \mathrm{v} / \mathrm{v})$ pumped at a flow rate of $1.0 \mathrm{~mL}$ $\min ^{-1}$ at $25^{\circ} \mathrm{C}$. The column effluent was detected at $265 \mathrm{~nm}$ by a UV detector (Waters 2489).

In vitro CDDP release. $\mathrm{PGP}-\mathrm{CDDP}$ and $\mathrm{PGP}-\mathrm{CDDP} / \mathrm{JQ1}$ (containing $0.5 \mathrm{mg}$ CDDP, dissolved in $5 \mathrm{~mL}$ buffer) were respectively added to a dialysis bag (MW 3,500 Da), and then immersed in $45 \mathrm{~mL}$ buffer under shaking $(90 \mathrm{rpm})$ at $37^{\circ} \mathrm{C}$ at two separate conditions: $10 \mathrm{mM}$ phosphate buffered saline (PBS) $\mathrm{pH} 7.4$ and $10 \mathrm{mM}$ PBS pH 6.8. At each desired time point (0, 12 h, 24 h, 48 h, 72 h, 96 h, 120 h, 148 h, $196 \mathrm{~h}), 5.0 \mathrm{~mL}$ of the release solution was withdrawn and $5.0 \mathrm{~mL}$ of the same fresh buffer was replaced in the PGP-CDDP group. At each desired time point ( $3 \mathrm{~h}, 6 \mathrm{~h}, 12$ h, $24 \mathrm{~h}, 48 \mathrm{~h}, 96 \mathrm{~h}, 120 \mathrm{~h}, 148 \mathrm{~h}, 196 \mathrm{~h}), 5.0 \mathrm{~mL}$ of the release solution was withdrawn 
and $5.0 \mathrm{~mL}$ of the same fresh buffer was replaced in the PGP-CDDP/JQ1 group. The release test was repeated in triplicate under the same conditions. Then, samples were diluted and the concentration of Pt were evaluated by ICP-MS.

Hydrodynamic radius and stability of nanomedicines. The diameter of the synthesized nanomedicines was determined by Dynamic light scattering and measured at different time points $(0 \mathrm{~h}, 24 \mathrm{~h}, 48 \mathrm{~h}, 72 \mathrm{~h})$ to assess the stability of the nanomedicines when stored at $4{ }^{\circ} \mathrm{C}$.

Cell culture. The mouse cervical cancer U14 cell line were purchased from Benia Chuanglian Bitotechnology Research Institute (Beina Biology Co. LTD, Beijing, China), it was used to perform the in vitro and in vivo studies and was incubated at 37 ${ }^{\circ} \mathrm{C}$ in an atmosphere of $5 \% \mathrm{CO}_{2}$. Cells were culture in DMEM, supplemented with 10 $\% \mathrm{FBS}, 50 \mathrm{U} / \mathrm{mL}$ penicillin and $50 \mathrm{U} / \mathrm{mL}$ streptomycin.

Cell viability assay, calculation of $\mathrm{IC}_{50}$ and combination index. The cytotoxicity of PGP-JQ1, PGP-CDDP, PGP-CDDP + PGP-JQ1, and PGP-CDDP/JQ1 was assessed by CCK-8 assay. U14 cells were seeded in 96-well plates at a density of 3500 cells per well in $200 \mu \mathrm{L}$ of complete DMEM and incubated for $24 \mathrm{~h}$. Then, the complete DMEM was removed and replaced with fresh culture medium, PGP-JQ1, PGP-CDDP, or PGP-CDDP + PGP-JQ1 at different molar ratio of PGP-CDDP: PGP-JQ1 (1:1, 1:2, 1:3, 1:5 and 1:10). The cells were subjected to CCK-8 assay after being incubated for another $72 \mathrm{~h}$. The absorbance of the solution was measured at 450 nm using a Bio-Rad 680 microplate reader. Cell viability (\%) was calculated according to the following equation: 
Viability $(\%)=\left(\mathrm{A}_{\text {sample }} / \mathrm{A}_{\text {control }}\right) \times 100$

In which $\mathrm{A}_{\text {sample }}$ and $\mathrm{A}_{\text {control }}$ represented the absorbance of the sample well and control well, respectively.

The reported data represented the average of three measurements from different batches. The dose effect profiles were plotted against the drug concentration in a logarithmic scale by a sigmoidal logistic fitting using OriginPro 9.1 (OriginLab, Northampton, MA) and the half maximal inhibitory concentration ( $\left.\mathrm{IC}_{50}\right)$ was calculated by Graghpad Prism 5.0 (GraphPad software, Inc, La Jolla, CA). The synergistic, additive, or antagonistic cytotoxic effects were evaluated by the combination index (CI) analysis according to the method of Chou-Talalay, using the following equation ${ }^{2}$ :

$$
\mathrm{CI}=\frac{(\mathrm{D})_{1}}{(\mathrm{Dx})_{1}}+\frac{(\mathrm{D})_{2}}{(\mathrm{Dx})_{2}}
$$

In which $(\mathrm{Dx})_{1}$ and $(\mathrm{Dx})_{2}$ represent the $\mathrm{IC}_{50}$ value of the drug 1 alone and drug 2 alone, respectively. (D) 1 and (D) 2 represent the concentration of drug 1 and drug 2 in the combination system at the $\mathrm{IC}_{50}$ value. Values of $\mathrm{CI}>1$ indicate antagonistic effect, $\mathrm{CI}=1$ indicate additive effect and $\mathrm{CI}<1$ indicate synergistic effect.

Colony formation assay. The cells were seeded into 6-well plates at a density of 100000 cells/well, and treated with PBS or nanomedicines for $6 \mathrm{~h}$. The cells were allowed to form colonies for 7-10 days. Then the colonies were fixed with $4 \%$ paraformaldehyde for 30 minutes and stained with $0.1 \%$ crystal violet (Sigma-Aldrich) 
for 10 minutes. The plates were washed and dried, images of the colonies were taken and the colonies were counted.

Apoptosis assay. U14 cells were seeded into 6-well plates at a density of 100000 cells/well, and treated with PGP-JQ1, PGP-CDDP, PGP-CDDP + PGP-JQ1, or PGP-CDDP/JQ1 for $16 \mathrm{~h}$, then collected and washed 3 times with PBS. The cells were resuspended in $100 \mu \mathrm{L} 1 \times$ binding buffer, then combined with $5 \mu \mathrm{L}$ Annexin V-FITC and $5 \mu \mathrm{L}$ propidium iodide (PI) and incubated for 30 minutes at room temperature in the dark. Next, $400 \mu \mathrm{L}$ binding buffer were added to the suspension. The samples were then immediately analyzed by flow cytometry (BD FACS Canto II).

Cell cycle analysis. U14 cells were seeded into 6-well plates at a density of 100000 cells/well, and treated with PGP-JQ1, PGP-CDDP, PGP-CDDP + PGP-JQ1, or PGP-CDDP/JQ1 for $72 \mathrm{~h}$. Next, the cells were harvested, washed 3 times with PBS and fixed with $70 \%$ ethanol at $4{ }^{\circ} \mathrm{C}$ overnight. Cells were centrifuged, washed and resuspended in cold PBS and incubated with Dyeing buffer, PI and RNase at $37{ }^{\circ} \mathrm{C}$ for 30 minutes in the dark. The cell cycle was evaluated by flow cytometry.

Animals and tumor-grafted models. Kunming mice (female, $18.0-22.0$ g, 4-5 weeks old) and BALB/c mice (female, $18.0-20.0 \mathrm{~g}, 5-6$ weeks) were purchased from the Beijing Vital River Laboratory Animal Technology Co. Ltd. (Beijing, China) and handled according to the protocol approved by the Institutional Animal Care and Use Committee of Jilin University. All efforts were made to minimize suffering. Pale yellow ascites were obtained from U14 tumor bearing Kunming mice. U14 cells were 
extracted from ascites, washed with PBS twice and diluted in normal PBS to a concentration of $1 \times 10^{7}$ cells $/ \mathrm{mL}$. Then, they were injected into the right flank of each $\mathrm{BALB} / \mathrm{c}$ mouse to generate the tumor-bearing mouse model.

In vivo antitumor efficacy. When the tumors reached $50 \mathrm{~mm}^{3}$, the mice were divided into Control group (treated with PBS), free JQ1 group (45.6 mg/kg on a JQ1 basis), PGP-JQ1 group (45.6 mg/kg on a JQ1 basis), PGP-CDDP group (6 mg/kg on a CDDP basis), PGP-CDDP (6 mg/kg on a CDDP basis) + PGP-JQ1 (45.6 mg/kg on a JQ1 basis) group, and PGP-CDDP/JQ1 (45.6 mg/kg on a JQ1 basis and $6 \mathrm{mg} / \mathrm{kg}$ on a CDDP basis) group. Tumor volume, tumor weight, and body weight were measured daily to evaluate the antitumor activity and systemic toxicity. The time corresponding to the achievement of a tumor volume of $2000 \mathrm{~mm}^{3}$ in each mouse was recorded to calculate the survival time.

The tumor suppression rate was calculated by the following formulas:

Tumor volume $=\mathrm{a} \times \mathrm{b}^{2} / 2$

In which $a$ and $b$ are the major and minor axes of the tumor measured by the caliper.

Tumor suppression rate $^{3}(\mathrm{TSR} \%)=100-(\mathrm{Ve} / \mathrm{Vc}) \times 100$

In which Ve and Vc are the experimental tumor volume and control tumor volume.

Histopathological analysis. At the end of the vivo antitumor study, the mice were sacrificed at the end of treatment, tumors and major organs from each group were harvested and fixed in $4 \%(\mathrm{w} / \mathrm{v})$ PBS-buffered paraformaldehyde for $48 \mathrm{~h}$, and then embedded in paraffin. The paraffin-embedded tumors and organs were cut into 5 
$\mu \mathrm{m}$-thick slices and stained with hematoxylin and eosin (H\&E). Histological images were taken under an optical microscope (IX71, Olympus, Tokyo, Japan). Necrotic areas were semi-quantitatively analyzed using photoshop software. Three mice were randomly selected from each group, and $10 \mathrm{H} \& \mathrm{E}$ slices of liver tissue of each mouse were selected to analyze the potential presence of metastatic foci of cervical cancer.

Drug toxicity analysis. Kunming mice were divided into Control group (treated with PBS), free JQ1 group (45.6 mg/kg on a JQ1 basis), PGP-JQ1 group (45.6 mg/kg on a JQ1 basis), PGP-CDDP group (6 $\mathrm{mg} / \mathrm{kg}$ on a CDDP basis), PGP-CDDP (6 $\mathrm{mg} / \mathrm{kg}$ on a CDDP basis) + PGP-JQ1 (45.6 mg/kg on a JQ1 basis) group, and PGP-CDDP/JQ1 group (45.6 mg/kg on a JQ1 basis and $6 \mathrm{mg} / \mathrm{kg}$ on a CDDP basis). The blood was collected from each mouse and placed in a sodium EDTA anticoagulant tube for hematological examination at $48 \mathrm{~h}$. The whole blood cellular components were counted and compared. Biochemical analysis was performed after obtaining the serum from the blood in a coagulation tube containing a separation tube. The myelosuppression effect was evaluated by measuring the serum level of white blood cells, red blood cells, and platelets. The liver function was evaluated by measuring the serum level of alanine aminotransferase, glutamic oxaloacetylase and cholinesterase. The kidney function was determined by measuring the serum blood urea nitrogen level.

Pharmacokinetics. Male Sprague Dawley rats, weighing $250 \pm 5$ g were randomly divided into three groups $(\mathrm{n}=3)$. Free JQ1, PGP-JQ1, and PGP-CDDP/JQ1 (15 $\mathrm{mg} / \mathrm{kg}$ on a JQ1 basis) were intravenously administered through the tail vein. Blood 
samples were collected from the orbital cavity at predefined time points $(3 \mathrm{~min}, 10$ min, 30 min, 2 h, 4 h, 8 h, 12 h, 24 h, 48 h), heparinized and centrifuged (2500 rpm, 5 min) to obtain the plasma. Each $60 \mu \mathrm{L}$ plasma sample was mixed with $1 \mathrm{~mL}$ Milli-Q water and $6 \mathrm{~mL}$ acetonitrile, vortexed for $10 \mathrm{~min}$ and blow-dried with nitrogen. Milli-Q water $100 \mu \mathrm{L}$ and acetonitrile $600 \mu \mathrm{L}$ were added to the solid powder, vortexed for $1 \mathrm{~min}$ and centrifuged at $12000 \mathrm{rpm}$. After filtration, the concentration of JQ1 was measured by HPLC. The HPLC system consisted of a reverse-phase C-18 column (Symmetry), and a mobile phase of acetonitrile and water $(80: 20 \mathrm{v} / \mathrm{v})$ pumped at a flow rate of $1.0 \mathrm{~mL} \mathrm{~min}{ }^{-1}$ at $25{ }^{\circ} \mathrm{C}$. The column effluent was detected at $265 \mathrm{~nm}$ using a UV detector (Waters 2489). Plasma pharmacokinetics software was used to calculate the drug retention half-life $\left(\mathrm{t}_{1 / 2}\right)$ and the area under the curve $\left(\mathrm{AUC}_{0-\infty}\right)$.

Male Sprague Dawley rats weighing $250 \pm 5 \mathrm{~g}$ were randomly divided into two groups $(\mathrm{n}=3)$. PGP-CDDP and PGP-CDDP/JQ1 $(1.97 \mathrm{mg} / \mathrm{kg}$ on a CDDP basis $)$ were intravenously administered through the tail vein. Blood samples were collected from the orbital cavity at predefined time points ( $3 \mathrm{~min}, 10 \mathrm{~min}, 2 \mathrm{~h}, 4 \mathrm{~h}, 8 \mathrm{~h}, 24 \mathrm{~h}, 48 \mathrm{~h}$ ). Heating with nitric acid $(1 \mathrm{~mL})$ at $80^{\circ} \mathrm{C}$ was used to decompose the samples until samples become clear, then Milli-Q water was used to volume the samples to $10 \mathrm{~mL}$. Then, samples were diluted by 1000 times and the concentration-time profiles of $\mathrm{Pt}$ at different times were evaluated by ICP-MS. Plasma pharmacokinetics software was used to calculate the drug retention half-life $\left(t_{1 / 2}\right)$ and the area under the curve $\left(\mathrm{AUC}_{0-\infty}\right)$. 
Biodistribution. BALB/c mice (female, $\mathrm{n}=3,18.0-20.0 \mathrm{~g}, 5-6$ weeks) were inoculated subcutaneously on the right flank with U14 cells. When the tumors reached $200 \mathrm{~mm}^{3}$, the mice were divided into free JQ1 group (15 mg/kg), PGP-JQ1 group (15 $\mathrm{mg} / \mathrm{kg}$ on a JQ1 basis) and PGP-CDDP/JQ1 (15 mg/kg on a JQ1 basis). The mice were sacrificed at $24 \mathrm{~h}$. The tumor, kidney, liver, spleen, lungs and heart were excised, then added $2.0 \mathrm{~mL}$ of methanol/water $(\mathrm{v} / \mathrm{v}=1: 1)$ solution per $0.5 \mathrm{~g}$ of tissue. After homogenized for $20 \mathrm{~s}$, the mixture was centrifuged at $2500 \mathrm{rpm}$ for $5 \mathrm{~min}$, the supernatant was collected and dried with a nitrogen blower. Milli-Q water $100 \mu \mathrm{L}$ and acetonitrile $600 \mu \mathrm{L}$ were added to the solid powder, vortexed for $1 \mathrm{~min}$ and centrifuged at $12000 \mathrm{rpm}$. After filtration, the concentration of JQ1 was measured by HPLC. The HPLC system consisted of a reverse-phase C-18 column (Symmetry), and a mobile phase of acetonitrile and water $(80: 20 \mathrm{v} / \mathrm{v})$ pumped at a flow rate of $1.0 \mathrm{~mL}$ $\min ^{-1}$ at $25{ }^{\circ} \mathrm{C}$. The column effluent was detected at $265 \mathrm{~nm}$ using a UV detector (Waters 2489).

BALB/c mice (female, $\mathrm{n}=3,18.0-20.0 \mathrm{~g}, 5-6$ weeks) were inoculated subcutaneously on the right flank with U14 cells. When the tumors reached $200 \mathrm{~mm}^{3}$, the mice were divided into free CDDP group (1.97 mg/kg), PGP-CDDP group (1.97 $\mathrm{mg} / \mathrm{kg}$ on a CDDP basis) and PGP-CDDP/JQ1 (1.97 mg/kg on a CDDP basis). The mice were sacrificed at $24 \mathrm{~h}$. The tumor, kidney, liver, spleen, lungs and heart were excised. The organs and tumor were decomposed with heat using nitric acid. Then Milli-Q water was used to volume the samples to $10 \mathrm{~mL}$. Then, samples were diluted and the concentration-time profiles of Pt were evaluated by ICP-MS. 
RNA-sequence (RNA-seq) analysis. U14 cells were seeded into 6-well plates at a density of 100000 cells/well, and treated with PGP-JQ1, PGP-CDDP or PGP-CDDP/JQ1 for $72 \mathrm{~h}$, collected and sequenced by RNA-seq (BGISEQ platform). The adjusted $\mathrm{Q}<0.001$ and $\log _{2}$ (Fold Change) $>1$ were set as the cut off criteria. Then the significantly and differentially expressed genes (DEGs) ${ }^{4}$ were found. The Kyoto Encyclopedia of Genes and Genomes (KEGG) ${ }^{5}$ is a collection of databases dealing with cellular processes, environmental information processing, genetic information processing, human disease, metabolism, organismal systems, and drug development. The significantly DEGs profiles in PGP-CDDP and PGP-JQ1 group were separately analyzed, as well as DEGs in the cellular processes were separately analyzed. The DEGs represented in both the PGP-CDDP group and PGP-JQ1 group were plotted in the Venn diagram. One circle represents one set of genes, the intersection of different circles represents the common genes in the different groups. The map network interactions helped to understand the relationship between genes and proteins. Solid lines represent the relationship between two nodes. The green line represents gene-gene interaction, which is called gene co-expression network, and red line represents protein-protein interaction, termed as PPI. The clustered heat maps were drawn using the data of gene expression.

Sanger sequence of U14 cells. The U14 cells at logarithmic growth phase were collected and sent to Sangon Biology Co. LTD for sanger sequence.

Quantitative real-time polymerase chain reaction (qPCR). U14 cells were seeded into 6-well plates at a density of 100000 cells/well, and treated with PGP-JQ1, 
PGP-CDDP or PGP-CDDP/JQ1 for $72 \mathrm{~h}$. Total RNA was extracted using the genomic RNA Extraction Kit (centrifugal column type, Biotetk, Wuxi, China) following the manufacturer's instructions. The cDNA was synthesized by reverse transcription from the total RNA (NovoScript 1st strand cDNA Synthesis SuperMix kit; Shanghai, China). qPCR was performed using the SYBR Green qPCR Master Mix (Thermo Fisher Scientific). The expression of Trp53 and Plk1 was normalized to the endogenous control mouse glyceraldehyde-3-phosphate dehydrogenase (GAPDH). The primer sequences of Trp53 and Plkl were designed according to RNA-seq results and synthesized in Sangon Biology Co. LTD. The primer of GAPDH was also purchased from Sangon Biology Co. LTD. The program cycle was the following: initial denaturation for $5 \mathrm{~min}$ at $95{ }^{\circ} \mathrm{C}$, followed by 40 cycles of 15 second at $95{ }^{\circ} \mathrm{C}$ and 60 second at $60{ }^{\circ} \mathrm{C}$. A melting curve was added at the end of the process. The relative gene expression was calculated using the $2^{-\Delta \Delta \mathrm{CT}}$ method.

Small interfering RNA (siRNA) transfection. Cells were seeded in 6-well plates at a concentration of 100000 cells/well. At $24 \mathrm{~h}$ post-culture, cells were transfected with siRNA sequences and GoldenTran-DR (molar ratio of 1:2), following the manufacturer's instructions. At $8 \mathrm{~h}$ after transfection, the nuclei were stained with 4',6-diamidino-2-phenylindole, while siRNA was bound to 5-carboxyfluorescein during construction, to show a green fluorescence. Laser confocal microscope (Olympus Corporation, Tokyo, Japan) was used to detect the amount of siRNA transfected into cells, to evaluate the siRNA transfection into the cells. At $48 \mathrm{~h}$ after transfection, qPCR was used to detect the expression of Plk1 and Trp53. 
Western blot analysis. Cells were seeded in $150 \mathrm{~mm}$ cell culture dishes at a concentration of $1 \times 10^{6}$ cells/dish, treated with PGP-JQ1, PGP-CDDP, or PGP-CDDP/JQ1 for $72 \mathrm{~h}$, then collected and frozen at $-80{ }^{\circ} \mathrm{C}$ for further use. Total proteins were extracted using RIPA lysis buffer. Protein concentration was determined using the BCA assay kit (Thermo Scientific, Rockford, IL, USA). An amount of $30 \mu \mathrm{g}$ protein was mixed with $5 \times$ loading buffer and boiled for $5 \mathrm{~min}$. Protein samples were loaded into 12\% SDS-PAGE gel and transferred onto a PVDF membrane (Millipore). $\beta$-actin was used as the loading control. The antibodies used were the following: mouse monoclonal anti-Plk1 (1:500, Abcam) and mouse monoclonal anti- $\beta$-actin (1:1000, Proteintech). The detected proteins were visualized using an enhanced chemiluminescence western blot detection system (GE AI600) and the bands were quantified using Image Quant TL.

Statistical analysis. Statistical analysis was performed using GraphPad Prism 5 software (GraphPad software, Inc, La Jolla, CA) and OriginPro 9.1 software (Origin software, OriginLab, USA). Winnonlin 8.1 software (Winnonlin software, NeoTrident Technology LTD, China) was used to calculate the drug $t_{1 / 2}$ and $\mathrm{AUC}_{0-\infty}$. All experiments were performed at least thrice and expressed as mean \pm standard deviation (SD). Statistical significance was determined using one-way analysis of variance (ANOVA) when different groups were compared. A value of $p<0.05$ was considered statistically significant. 


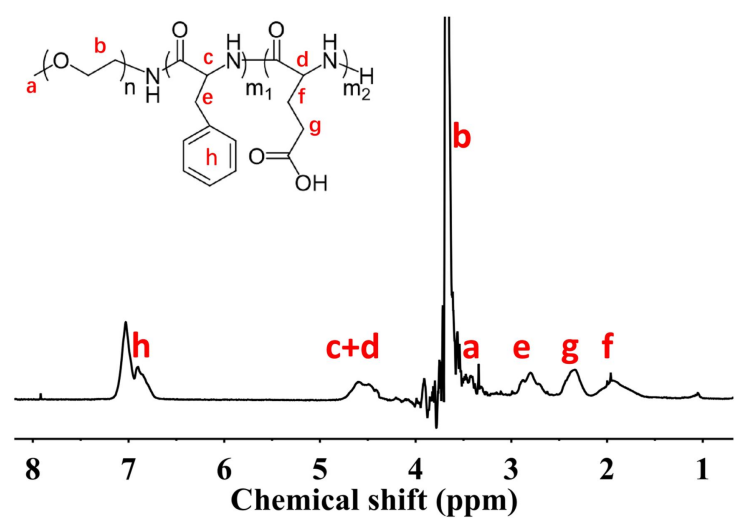

Figure S1. ${ }^{1} \mathrm{H}$ NMR spectrum of PGP in trifluoroacetic acid-d (TFA-d).
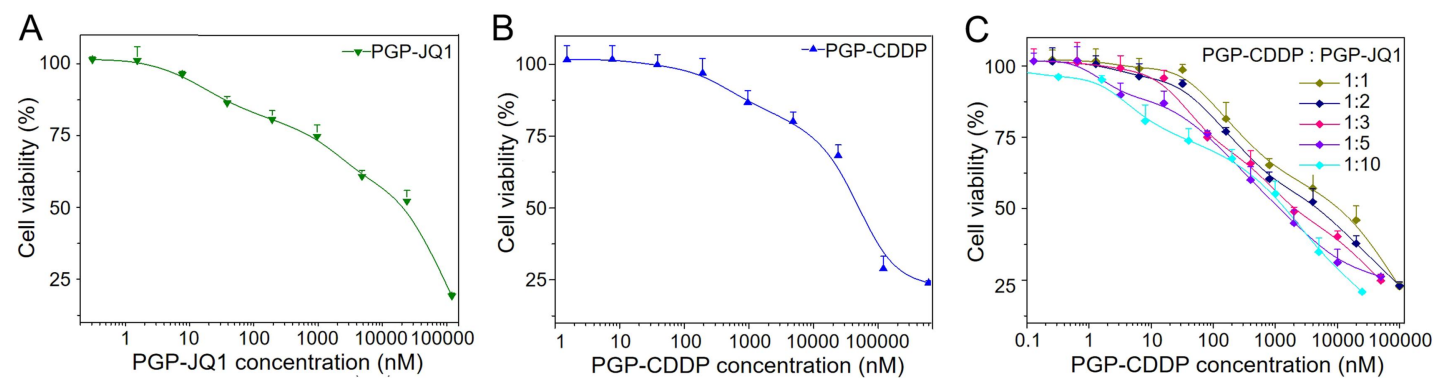

Figure S2 (A-C). Cytotoxicity of PGP-JQ1, PGP-CDDP, and CDDP and JQ1 at different molar ratios $(1: 1,1: 2,1: 3,1: 5,1: 10)$ on U14 cells for $72 \mathrm{~h}$, and subjected to CCK-8 assay. Results were presented as mean \pm SD $(n=3)$. 
A

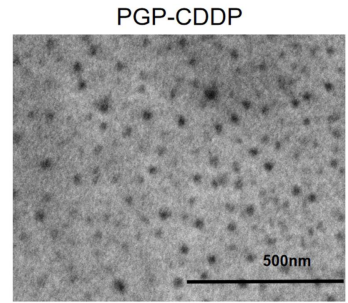

B

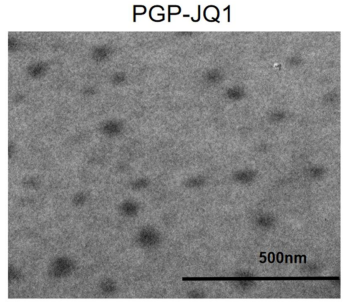

C

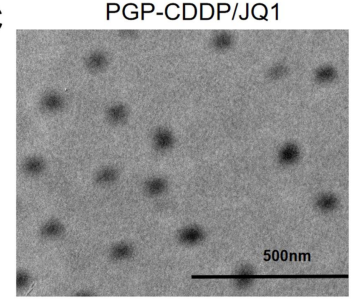

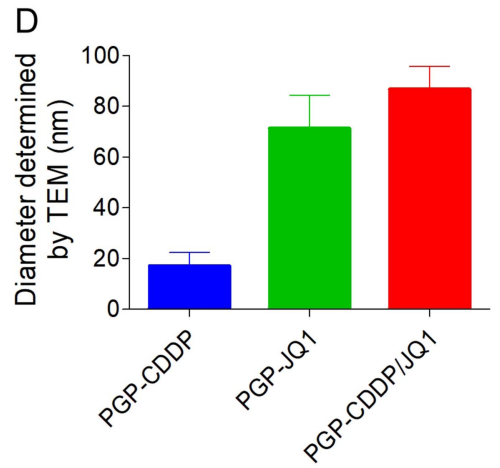

Figure S3 (A-C). The TEM images of PGP-CDDP (A), PGP-JQ1 (B), PGP-CDDP/JQ1 (C), scale bar $=500 \mathrm{~nm}$. (D) The diameter of each nanoparticle determined by TEM. 50 nanoparticles of PGP-CDDP, PGP-JQ1 and PGP-CDDP/JQ1 in TEM were respectively selected and the average diameter was calculated. Data are presented as the mean $\pm \mathrm{SD}$.
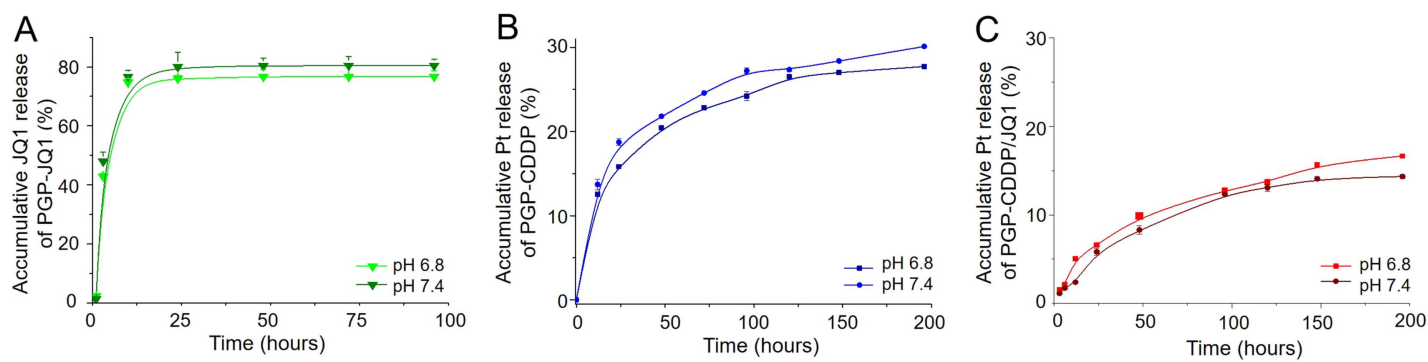

Figure S4. (A) In vitro accumulative JQ1 release from PGP-JQ1 in PBS at $\mathrm{pH} 6.8$ and 7.4 at $37{ }^{\circ} \mathrm{C}$. (B-C) In vitro accumulative Pt release from PGP-CDDP (B) and PGP-CDDP/JQ1 (C) in PBS at pH 6.8 and 7.4 at $37^{\circ} \mathrm{C}$. 

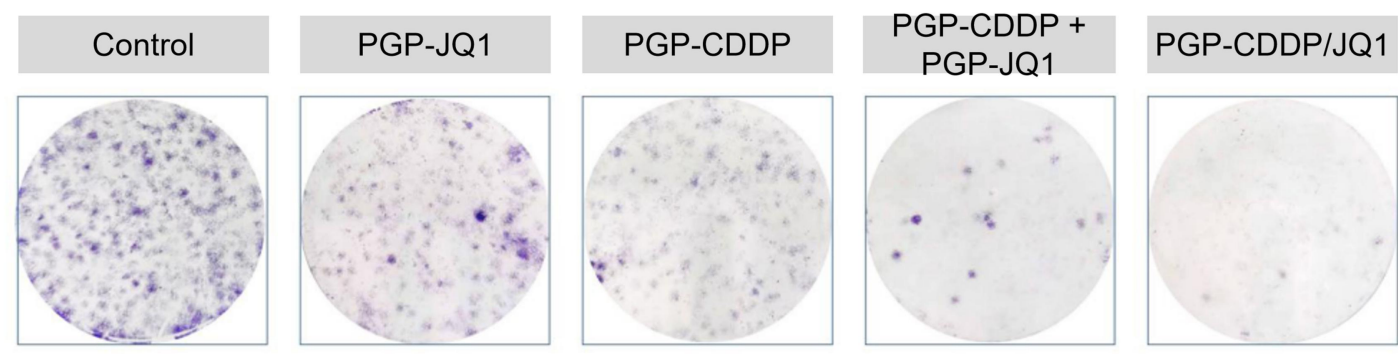

Figure S5. Images of U14 colonies in different groups. U14 cells were treated with PBS and nanomedicines for $6 \mathrm{~h}$ and allowed to form colonies for 7-10 days. The colonies of U14 cells in different groups were shown by the purple color obtained by the staining with crystal violet, and images were taken.
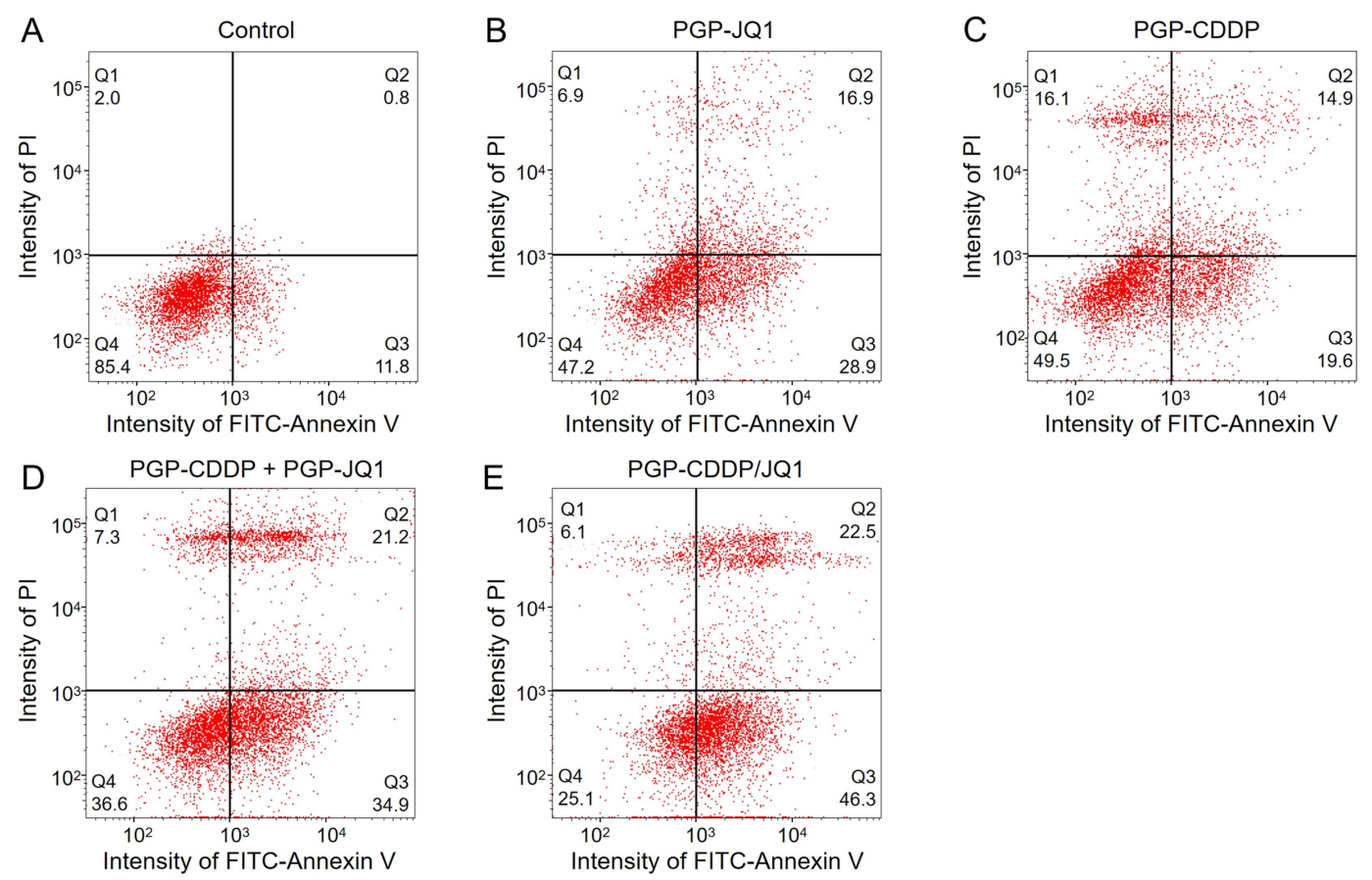

Figure S6. Cell apoptosis in U14 cells treated with different nanomedicines. U14 cells were treated with PBS and nanomedicines for $16 \mathrm{~h}$, then cells were stained by PI and FITC labeled annexin V and subjected to flow cytometry. 

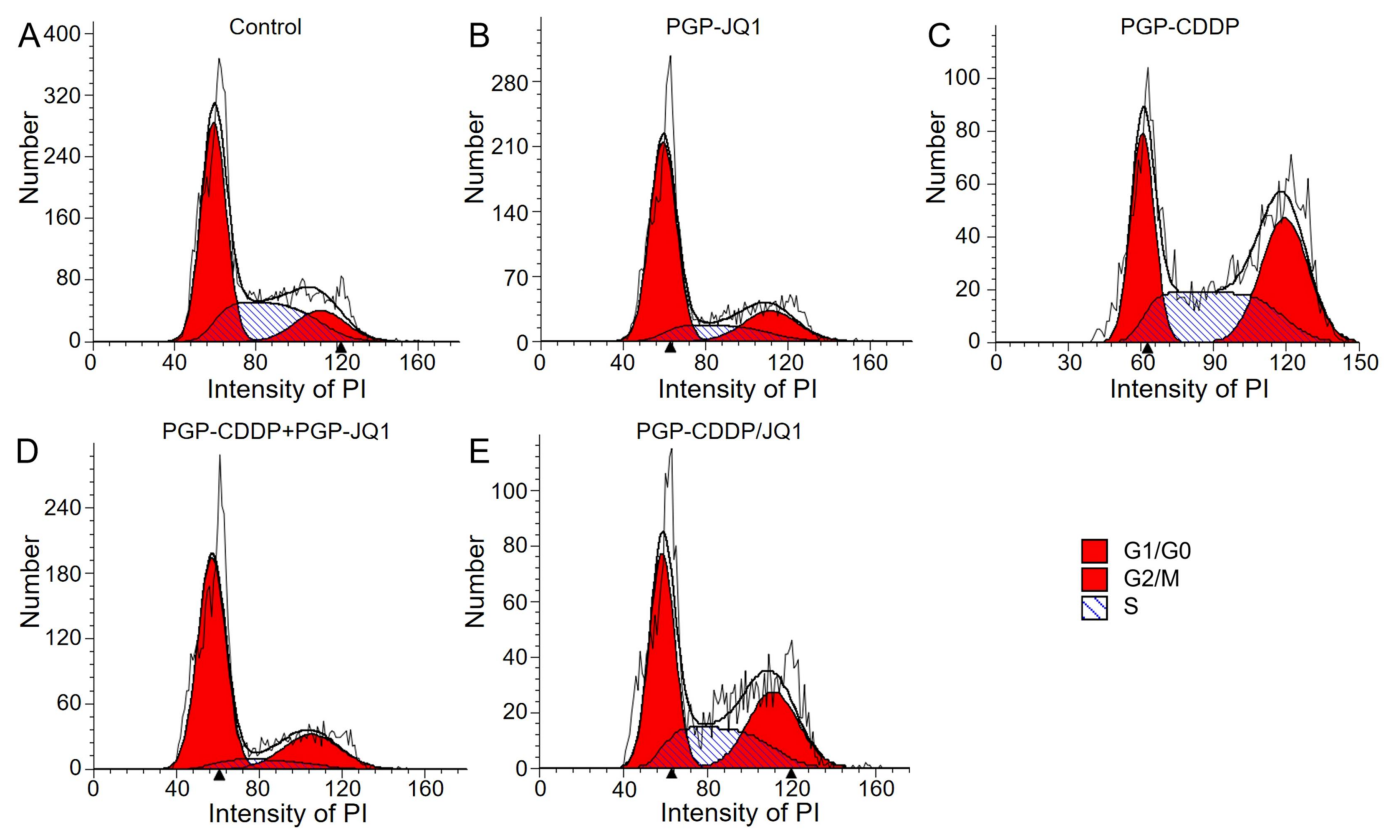

Figure S7 (A-E). Cell cycle distribution in U14 cells treated with different nanomedicines. U14 cells were treated with PBS and nanomedicines for $72 \mathrm{~h}$, then cell cycle distribution (G1/G0, G2/M, S) was evaluated by PI and analyzed by flow cytometry.
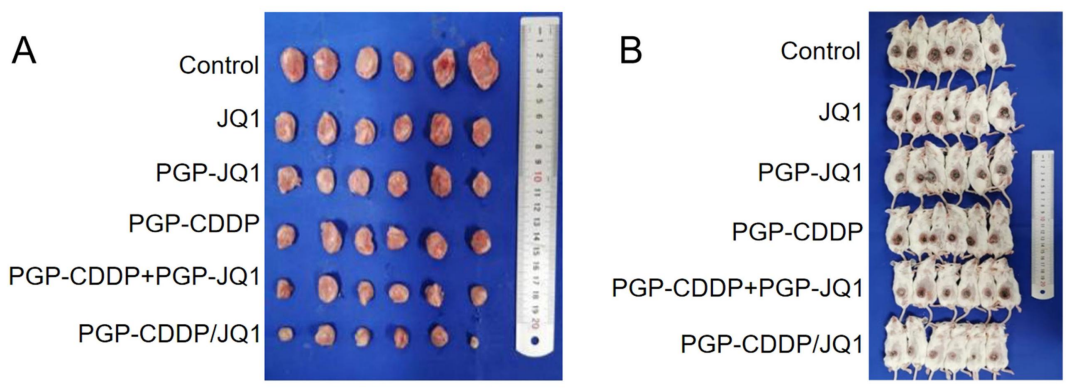

Figure S8 (A-B). Images of tumors and mice. U14 tumor bearing BALB/c mice were treated with PBS (Control group), free JQ1, PGP-JQ1, PGP-CDDP, PGP-CDDP + PGP-JQ1 or PGP-CDDP/JQ1 at a dose of $6 \mathrm{mg} / \mathrm{kg}$ on CDDP and $45.6 \mathrm{mg} / \mathrm{kg}$ on JQ1 basis (molar ratio CDDP: JQ1 of 1:5) on day $0,3,7$, and 10 . Images of the tumors (A) and mice (B) in different groups were taken after the treatment. 


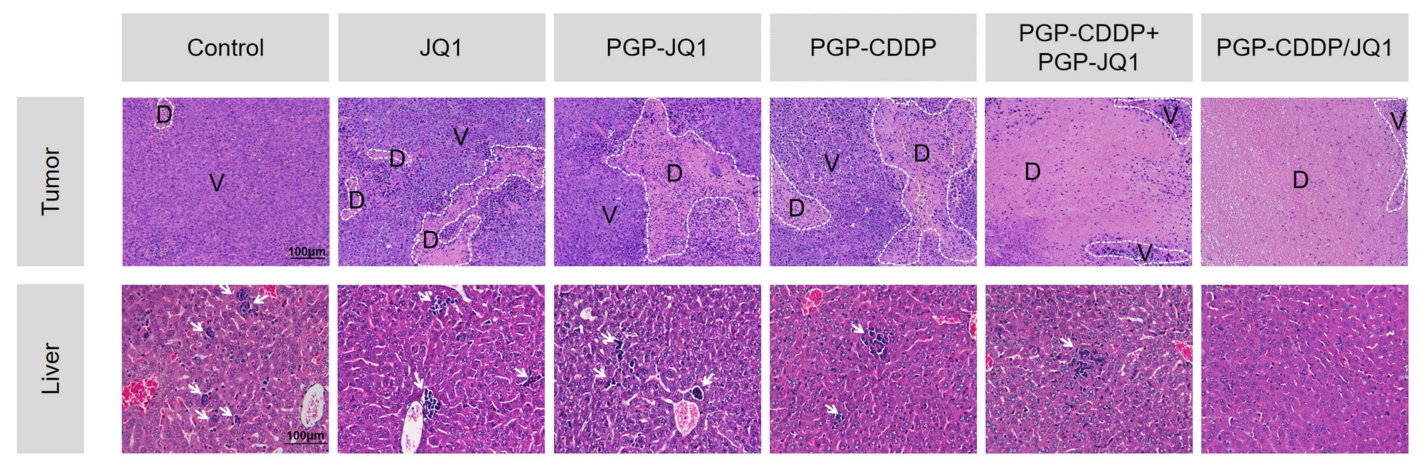

Figure S9. H\&E staining of tumor $(\mathrm{n}=8 \mathrm{mice} /$ group $)$ and liver $(\mathrm{n}=3$ mice with 10 fields per animal) on day 16 after the first treatment. Nuclei were stained bluish violet, extracellular matrix and cytoplasm were stained pink in H\&E. D: region of dead cells in the tumor; V: region of viable cells in the tumor. The arrow pointed the area of hepatic metastasis of cervical cancer in liver H\&E staining.

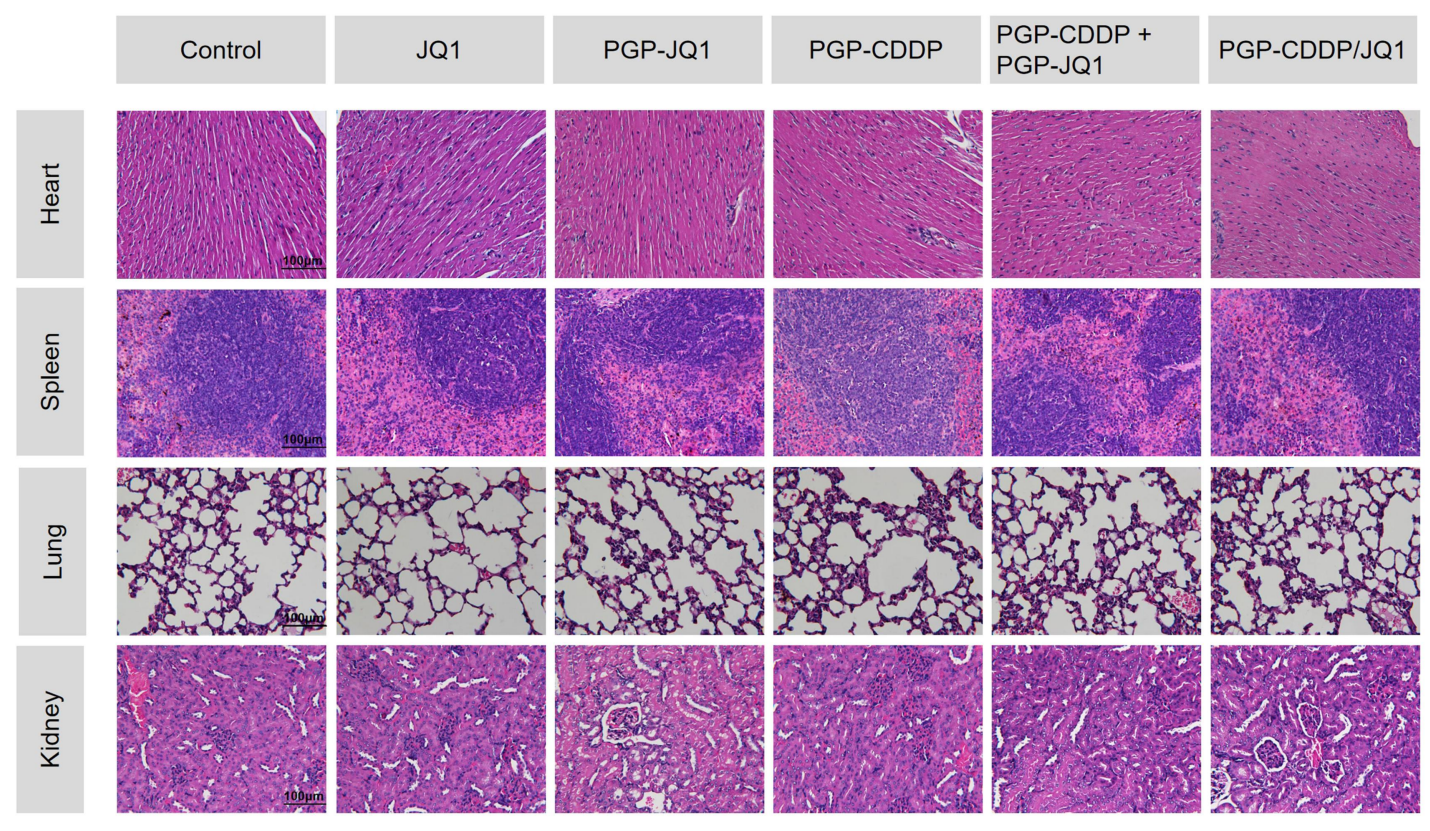

Figure S10. H\&E staining of normal tissue (heart, spleen, lung and kidney) in U14 tumor-bearing mice treated with different nanomedicines. 

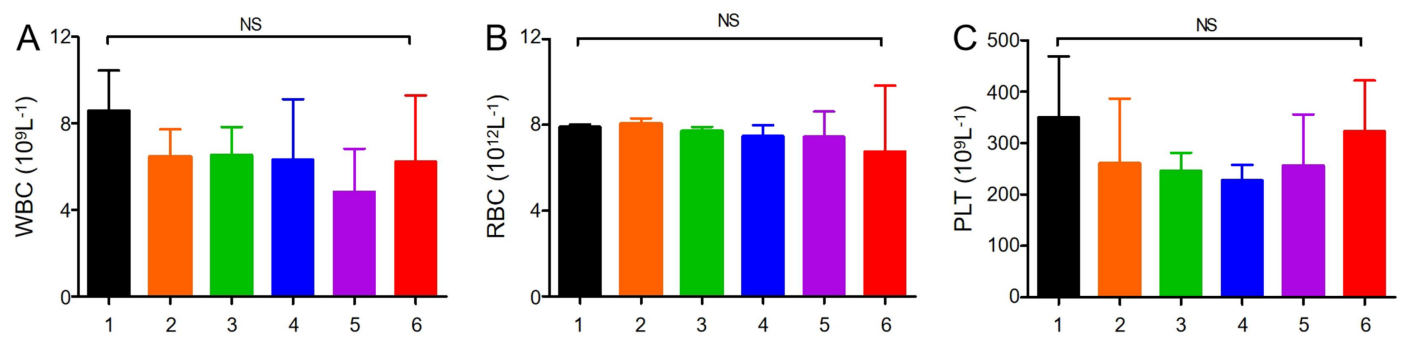

Figure S11 (A-C). The content of white blood cells (WBCs), red blood cells (RBCs), and platelets (PLTs) in the serum was monitored at day 2 of the treatment with PBS (1), free JQ1 (2), PGP-JQ1 (3), PGP-CDDP (4), PGP-CDDP + PGP-JQ1 (5) or PGP-CDDP/JQ1 (6) at a dose of $6 \mathrm{mg} / \mathrm{kg}$ on CDDP and $45.6 \mathrm{mg} / \mathrm{kg}$ on JQ1 basis. Results are shown as mean \pm SD. NS: not significant.
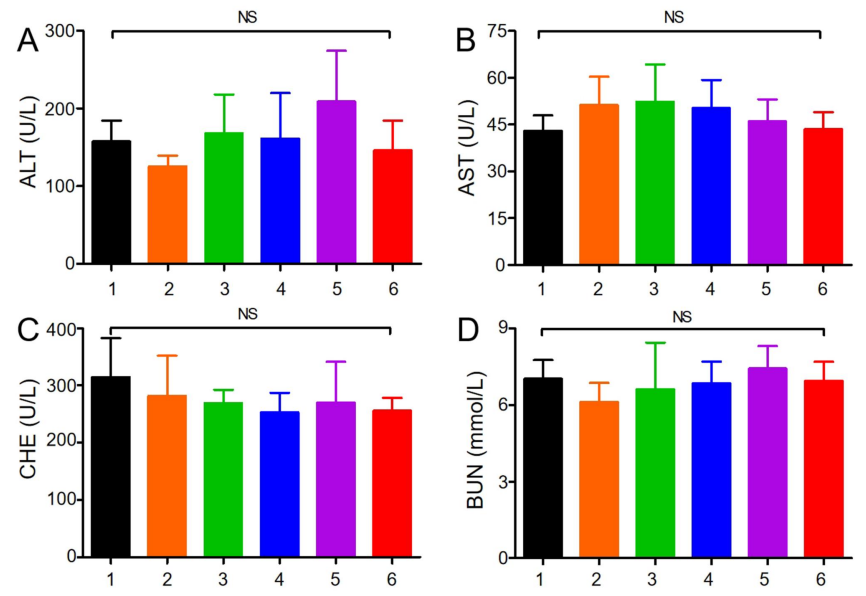

Figure S12 (A-D). Serum alanine aminotransferase (ALT), aspartate aminotransferase (AST), cholinesterase (CHE) and urea nitrogen (BUN) levels were monitored using the same method described in Figure S11. 

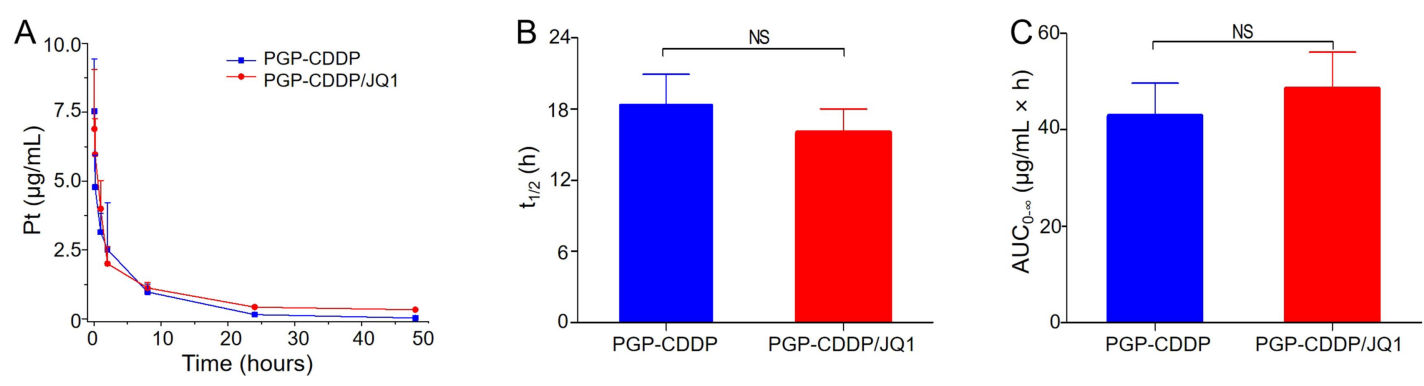

Figure S13. Sprague Dawley rats were treated with PGP-CDDP and PGP-CDDP/JQ1 at a dose of $1.97 \mathrm{mg} / \mathrm{kg}$ CDDP. (A) Plasma concentration-time profiles of Pt at different times were evaluated by ICP-MS. (B-C) Plasma pharmacokinetic parameters: $t_{1 / 2}(B)$ and $\mathrm{AUC}_{0-\infty}(\mathrm{C})$ of Pt in PGP-CDDP and PGP-CDDP/JQ1. Results were expressed as mean \pm SD. NS: not significant.
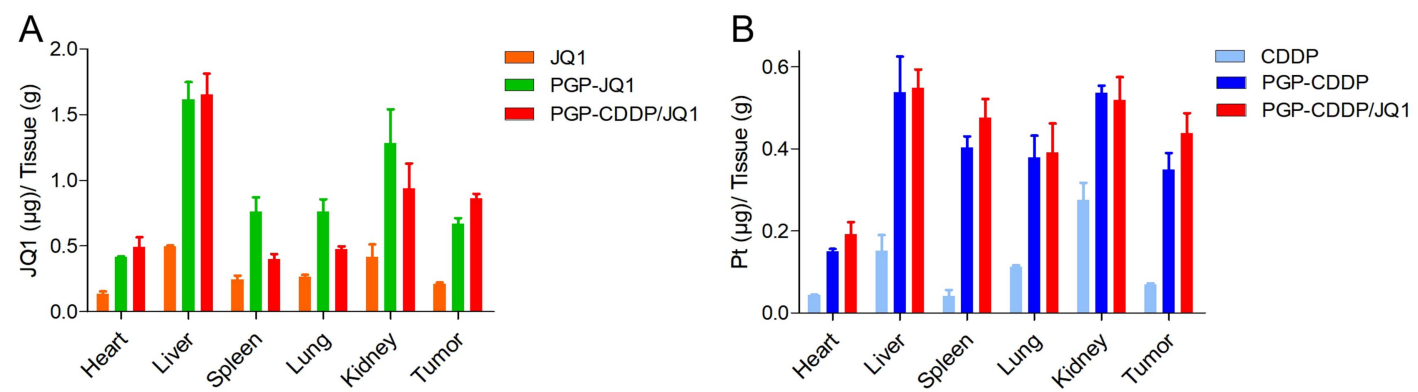

Figure S14. (A) Biodistribution of JQ1 at $24 \mathrm{~h}$ after a single injection of free JQ1, PGP-JQ1 or PGP-CDDP/JQ1 at a dose of $15 \mathrm{mg} / \mathrm{kg}$ JQ1. (B) Biodistribution of Pt at $24 \mathrm{~h}$ after a single injection of free CDDP, PGP-CDDP or PGP-CDDP/JQ1 at a dose of $1.97 \mathrm{mg} / \mathrm{kg}$ CDDP in mice. 

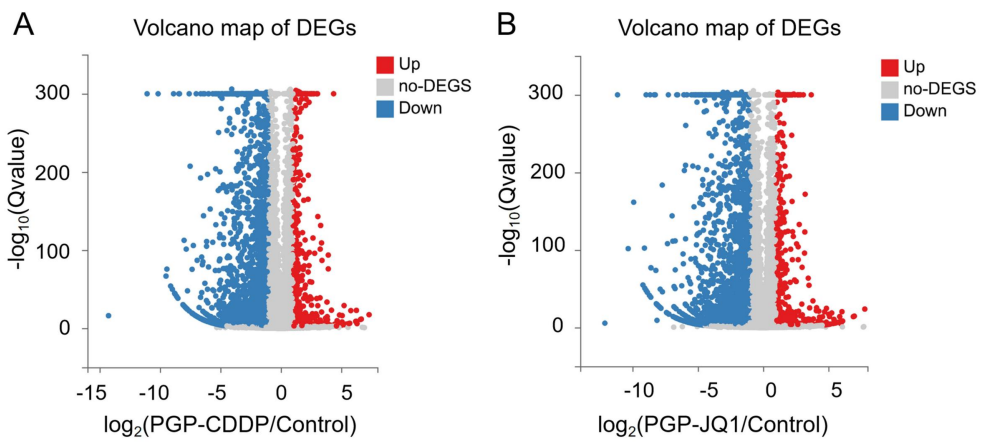

Figure S15 (A-B). The volcano plot of fold changes in the PGP-CDDP and PGP-JQ1 group. U14 cells were treated with PGP-JQ1, PGP-CDDP, and PGP-CDDP/JQ1 for $72 \mathrm{~h}$ and then collected and sequenced by RNA-seq. $\log _{2}$ of fold-change were present on the axis. Red, blue and gray dots represented significantly up-, down-regulated and no-regulated genes $\left(\mid \log _{2}\right.$ (fold-change) $\left.\mid>1\right)$.

A

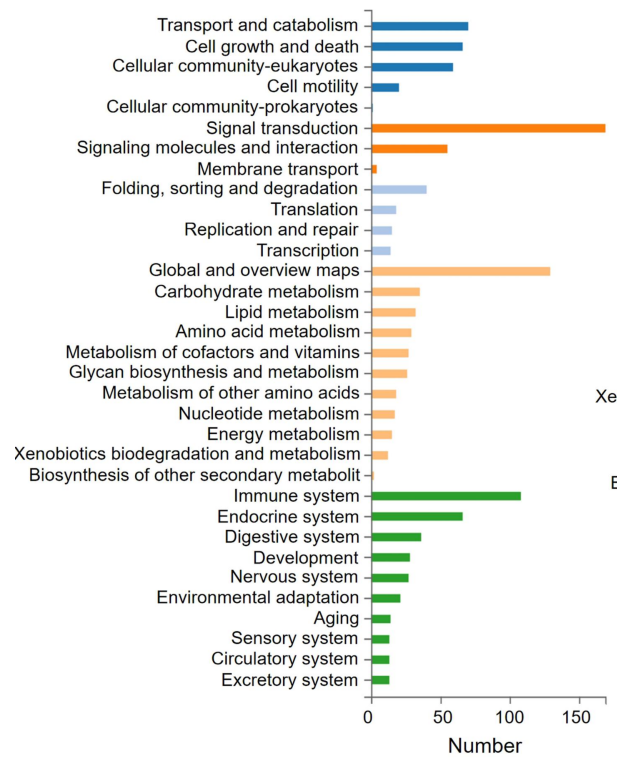

B KEGG-pathway Classification

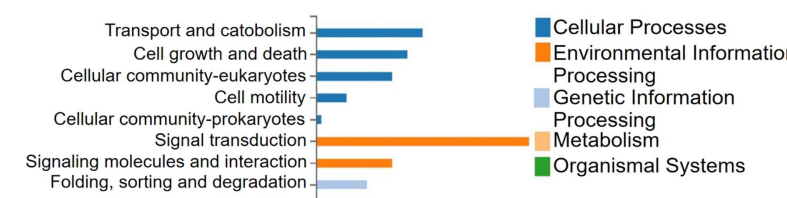

Signaling molecules and interaction degradationTranslation-
Transcription Replication and repair Global and overview map Lipid metabolism

Amino acid metabolism

Carbohydrate metabolism Metabolism of other amino acids Glycan biosynthesis and metabolism (ictics biodegradation and metabolism Metabolism of cofactors and vitamins Nucleotide metabolism Biosynthesis of other seconday metabolit condary metabolit Endocrine system Digestive system Development Nervous system Excretory system Sensory system Environmental adaptation $\begin{array}{lllll}0 & 10 & 20 & 30 & 40\end{array}$

Figure S16 (A, B). KEGG pathway enrichment analysis of DEGs in PGP-CDDP group (A) and PGP-JQ1 group (B), according to the RNA-seq analysis of the U14 cells. 


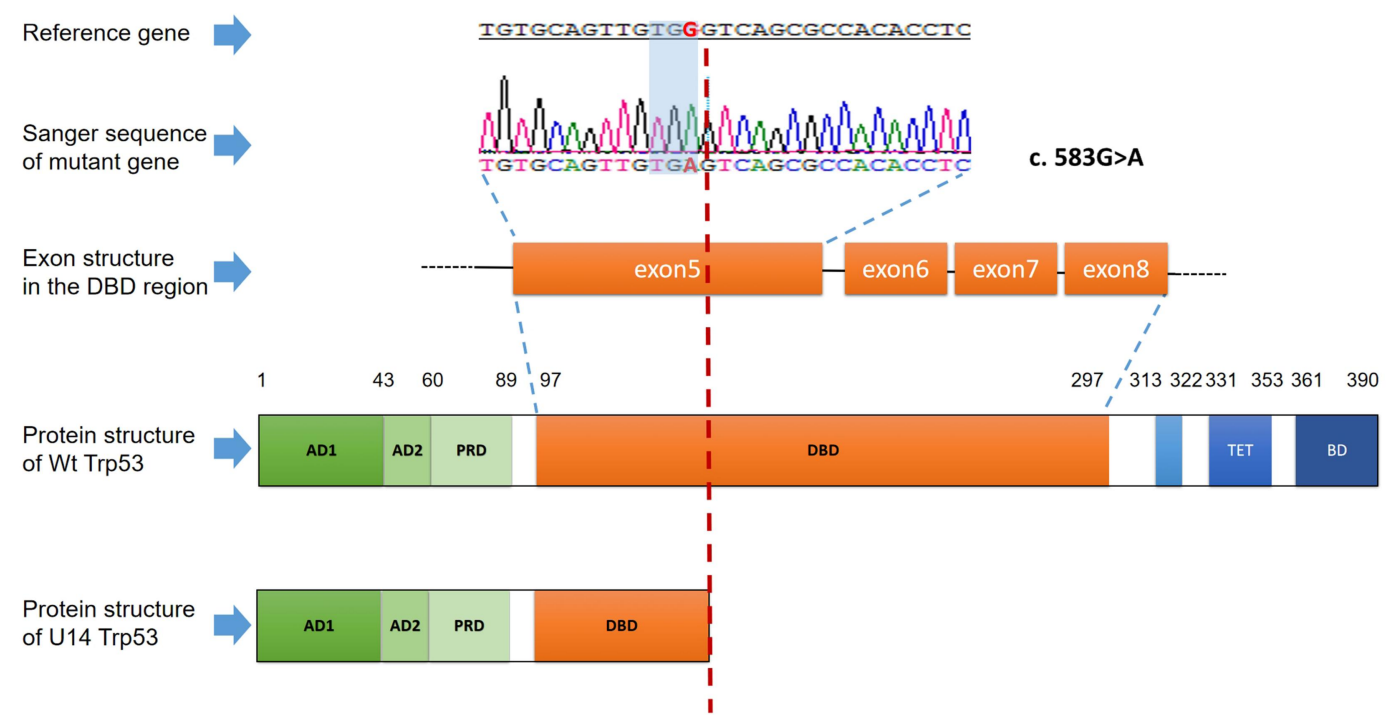

Figure S17. The sanger sequence and protein structure of Trp53 in U14 cell line. A $\mathrm{TGG} \rightarrow$ TGA nonsense mutation at codon 583 in exon 5 of $\operatorname{Trp} 53$ were detected in the U14 cell line, resulting in a truncation of the p53 protein, compared with the protein structure of Wt Trp53.
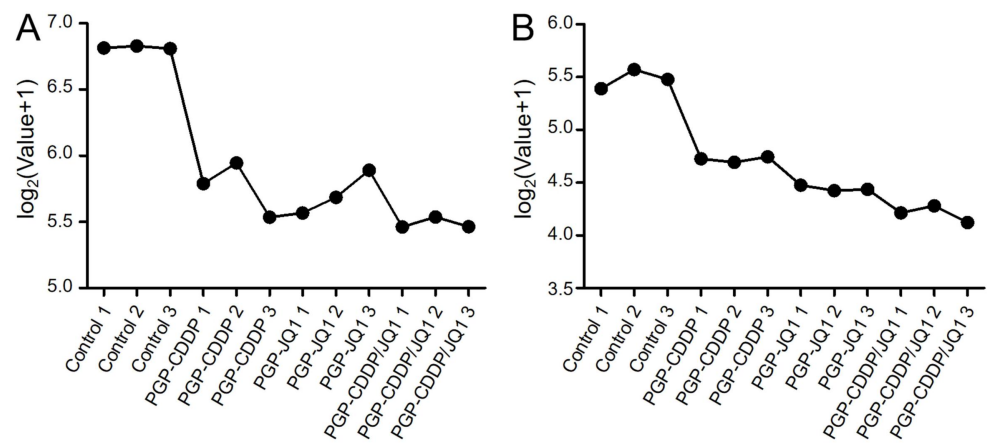

Figure S18 (A-B). The mRNA expression line chart of Trp53 (A) and Plk1 (B) according to the RNA-seq analysis of the U14 cells. 
Table S1. Characterization of the nanomedicines

\begin{tabular}{llll}
\hline Drugs & Feed ratio (\%) & DLC (\%) & DLE (\%) \\
\hline PGP-CDDP & $20 \%$ & 4.9 & 24.5 \\
PGP-JQ1 & $20 \%$ & 8.12 & 40.6 \\
\hline
\end{tabular}

DLC: the drug loading content

DLE: the drug loading efficiency

Table S2. $\mathrm{IC}_{50}$ and $\mathrm{CI}$ values for combination treatment

\begin{tabular}{|c|c|c|c|c|c|c|c|}
\hline & \multirow{2}{*}{ PGP-CDDP } & \multirow{2}{*}{ PGP-JQ1 } & \multicolumn{5}{|c|}{$\begin{array}{l}\text { PGP-CDDP }+ \text { PGP-JQ1 with } \\
\text { different molar ratio (CDDP:JQ1) }\end{array}$} \\
\hline & & & $1: 1$ & $1: 2$ & $1: 3$ & $1: 5$ & $1: 10$ \\
\hline $\mathrm{CDDP} \mathrm{IC}_{50}(\mu \mathrm{M})$ & 51.76 & & 7.80 & 4.55 & 2.58 & 1.52 & 1.07 \\
\hline $\mathrm{JQ}_{1} \mathrm{IC}_{50}(\mu \mathrm{M})$ & & 13.00 & 7.80 & 9.10 & 7.74 & 7.60 & 10.70 \\
\hline $\begin{array}{l}\text { CI of PGP-CDDP } \\
+ \text { PGP-JQ1 }\end{array}$ & & & 0.75 & 0.79 & 0.65 & 0.61 & 0.84 \\
\hline
\end{tabular}

$\mathrm{IC}_{50}$ : the half maximal inhibitory concentration

CI: combination index 
Table S3. The DLC (\%), mass ratio and molar ratio of CDDP and JQ1 in PGP-CDDP /JQ1 prepared with different feeding ratios of CDDP and JQ1

\begin{tabular}{|c|c|c|c|c|}
\hline & $\begin{array}{l}\text { Feeding ratio } \\
(\mathrm{w} / \mathrm{w})\end{array}$ & DLC (\%) & $\begin{array}{l}\text { Mass ratio } \\
\text { (CDDP:JQ1) }\end{array}$ & $\begin{array}{l}\text { Molar ratio } \\
\text { (CDDP:JQ1) }\end{array}$ \\
\hline CDDP & $1.25 \%$ & $0.765 \%$ & $1: 7.6$ & $1: 5$ \\
\hline $\begin{array}{l}\text { JQ1 } \\
\end{array}$ & $20 \%$ & $5.8 \%$ & & \\
\hline CDDP & $2.5 \%$ & $1.53 \%$ & $1: 4.5$ & $1: 2.8$ \\
\hline JQ1 & $20 \%$ & $6.9 \%$ & & \\
\hline CDDP & $5 \%$ & $2.5 \%$ & $1: 3.2$ & $1: 2$ \\
\hline JQ1 & $20 \%$ & $8.17 \%$ & & \\
\hline CDDP & $10 \%$ & $6.8 \%$ & $1: 1.5$ & $1: 1$ \\
\hline JQ1 & $20 \%$ & $10.15 \%$ & & \\
\hline
\end{tabular}

DLC: the drug loading content

Table S4. The Zeta Potential of different nanoparticles in distilled water

\begin{tabular}{ll}
\hline Nanoparticles & Zeta Potential $(\mathrm{mV})$ \\
\hline PGP & $-33.33 \pm 2.08$ \\
PGP-JQ1 & $-31.60 \pm 2.34$ \\
PGP-CDDP & $-10.67 \pm 2.01$ \\
PGP-CDDP/JQ1 & $-27.50 \pm 3.50$ \\
\hline
\end{tabular}


Table S5. The $\mathrm{IC}_{50}$ and CI values for PGP-CDDP + PGP-JQ1 and PGP-CDDP/JQ1

\begin{tabular}{|c|c|c|c|c|}
\hline & PGP-CDDP & PGP-JQ1 & $\begin{array}{l}\text { PGP-CDDP }+ \\
\text { PGP-JQ1 }^{\mathrm{a}}\end{array}$ & PGP-CDDP/JQ1 ${ }^{\mathrm{a}}$ \\
\hline $\begin{array}{l}\mathrm{CDDP} \mathrm{IC}_{50} \\
(\mu \mathrm{M})\end{array}$ & 48.47 & & 1.16 & 0.62 \\
\hline JQ1 IC ${ }_{50}(\mu \mathrm{M})$ & & 15.80 & 5.80 & 3.10 \\
\hline CI & & & 0.39 & 0.21 \\
\hline
\end{tabular}

\footnotetext{
$\mathrm{IC}_{50}$ : the half maximal inhibitory concentration

CI: combination index

a. molar ratio of CDDP: JQ1 was 1:5
}

Table S6. The 22 genes on Pubmed which may be potential targets to treat Trp53-mutant cancers ${ }^{6}$

\begin{tabular}{|c|c|c|}
\hline & Genes & Mechanisms of Action \\
\hline $1-2$ & Chk1/2 & suppression of the G2/M checkpoint to induce cell death ${ }^{7,8}$. \\
\hline 3 & Mapkapk2 & $\begin{array}{l}\text { regulator of the } \mathrm{G} 2 / \mathrm{M} \text { checkpoint by sustaining the } \mathrm{G} 2 / \mathrm{M} \\
\text { checkpoint in response to genotoxic stress or UV irradiation }{ }^{9,10} \text {. }\end{array}$ \\
\hline 4 & Plk1 & $\begin{array}{l}\text { controls } \mathrm{G} 2 / \mathrm{M} \text { checkpoint to induce synthetic lethality in cells } \\
\text { with p53 mutations }{ }^{11,12} \text {. }\end{array}$ \\
\hline 5 & Wee1 & $\begin{array}{l}\text { Wee1 kinase plays an important role in p53-mutant head and } \\
\text { neck squamous cell carcinoma }{ }^{13,14} \text {. }\end{array}$ \\
\hline 6 & Sgk2 & its depletion induces autophagy ${ }^{15}$. \\
\hline 7 & Mpeg1 & $\begin{array}{l}\text { its inhibition reduces cell viability and increased cell death } \\
\text { selectively in p53-mutant breast cancer }{ }^{16,17} \text {. }\end{array}$ \\
\hline 8 & Pip4k2b & $\begin{array}{l}\text { its inhibition reduces the growth of } \mathrm{p} 53 \text {-mutant breast cancer by } \\
\text { inhibiting glucose metabolism and increasing the levels of } \\
\operatorname{ROS}^{18,19} \text {. }\end{array}$ \\
\hline 9 & $\mathrm{Hk} 2$ & $\begin{array}{l}\text { Hk2-mediated aerobic glycolysis, known as the Warburg effect, } \\
\text { is required for p53-deficienct tumor growth }{ }^{20} \text {. }\end{array}$ \\
\hline
\end{tabular}


10 Mapk14 its inhibition preferentially suppresses tumor growth of breast cancer expressing the mutant $\mathrm{p} 53^{21}$.

11 Dapk1 its depletion or inhibition suppresses the growth of p53-mutant ${ }^{22}$.

12 Tlr3 targeting the mutant p53 to increase Tlr3 expression may enhance the antitumor immune responses in cancer cells harboring specific p53 mutations ${ }^{23}$.

13 Tlr4 in p53-mutant breast cancer cells, Tlr4 activation promotes tumor growth by inducing the secretion of CXCL1 and CD15424.

14 Ets2 mutant p53 is recruited to chromatin via interaction with transcription factor Ets $2^{25}$.

15 Pdgfr $\beta \quad$ PDGFR $\beta$ signaling enhances the expression of a GOF mutant p53. Its inhibition effectively prevents cell invasion and metastasis of pancreatic cancer with p53 mutations ${ }^{26}$.

16 Pla2g16 It is a p53-regulated gene. Its knockdown inhibits migration and invasion in mutant $\mathrm{p} 53$-expressing cells ${ }^{27}$.

$17 \mathrm{Kmt} 2 \mathrm{a} / \quad$ specifically upregulated in p53 GOF patient-derived tumors ${ }^{28}$.

$18 \mathrm{Km} 2 \mathrm{~d} /$

19 Kat6a

20 Tdp2 It is involved in the repair of DNA damage caused by the chemotherapeutic drug etoposide, as a transcriptional target of mutant $\mathrm{p} 53^{29}$.

21 Hdac6 disruption of HDAC6/HSP90 complex induces the degradation of mutant $\mathrm{p} 53^{30}$.

22 Dnaja1 It controls the fate of misfolded mutant p53 through the mevalonate pathway ${ }^{31}$. 
Table S7. Primers used on qPCR

\begin{tabular}{lll}
\hline Murine gene & sequence & \\
\hline Trp53 & sense & 5'-GGGCAACTATGGCTTCCACC-3' \\
& antisense & 5'-CTGACCCACAACTGCACAGG-3' \\
Plk1 & sense & 5'-CTGACCCACAACTGCACAGG-3' \\
& antisense & 5'-ATGACCTGATTGCGGTGCAG-3' \\
GAPDH & sense & 5'-AGGTCGGTGTGAACGGATTTG-3' \\
& antisense & 5'-GGGGTCGTTGATGGCAACA-3' \\
\hline
\end{tabular}

Table S8. The Plk1 siRNA sequences

\begin{tabular}{lll}
\hline & Sequence & \\
\hline siRNA & sense & 5'-FAM-GCAGCAGGAAACCUCUCAATT-3' \\
& antisense & 5'-UUGAGAGGUUUCCUGCUGCTT-3' \\
si-Control & sense & 5'-UUCUCCGAACGUGUCACGUTT-3' \\
& antisense & 5'-ACGUGACACGUUCGGAGAATT-3'
\end{tabular}

FMA: 5-carboxyfluorescein 
References

(1) Lv, S.; Song, W.; Tang, Z.; Li, M.; Yu, H.; Hong, H.; Chen, X. Charge-Conversional PEG-Polypeptide Polyionic Complex Nanoparticles from Simple Blending of a Pair of Oppositely Charged Block Copolymers as an Intelligent Vehicle for Efficient Antitumor Drug Delivery. Mol Pharm 2014, 11, (5), 1562-74.

(2) Chou, T. C.; Talalay, P. Quantitative analysis of dose-effect relationships: the combined effects of multiple drugs or enzyme inhibitors. Adv Enzyme Regul 1984, 22 , 27-55.

(3) Yang, S.; Tang, Z,.; Hu, C.;Zhang, D.;Shen, N.;Yu, H.;Chen, X.; Selectively Potentiating Hypoxia Levels by Combretastatin A4 Nanomedicine: Toward Highly Enhanced Hypoxia-Activated Prodrug Tirapazamine Therapy for Metastatic Tumors. Adv Mater 2019, 31, (11), e1805955.

(4) Wang, L.; Feng, Z.; Wang, X.; Wang, X.; Zhang, X. DEGseq: an R package for identifying differentially expressed genes from RNA-seq data. Bioinformatics 2010, 26, (1), 136-8.

(5) Kanehisa, M.; Araki, M.; Goto, S.; Hattori, M.; Hirakawa, M.; Itoh, M.; Katayama, T.; Kawashima, S.; Okuda, S.; Tokimatsu, T.; Yamanishi, Y. KEGG for linking genomes to life and the environment. Nucleic Acids Res 2008, 36, (Database issue), D480-4.

(6) Zhao, D.; Tahaney, W. M.; Mazumdar, A.; Savage, M. I.; Brown, P. H. Molecularly Targeted Therapies for p53-mutant Cancers. Cell Mol Life Sci 2017, 74, (22), 4171-4187.

(7) Origanti, S.; Cai, S. R.; Munir, A. Z.; White, L. S.; Piwnica-Worms, H. Synthetic lethality of Chk1 inhibition combined with p53 and/or p21 loss during a DNA damage response in normal and tumor cells. Oncogene 2013, 32, (5), 577-88.

(8) Toledo, L. I.; Murga, M.; Zur, R.; Soria, R.; Rodriguez, A.; Martinez, S.; Oyarzabal, J.; Pastor, J.; Bischoff, J. R.; Fernandez-Capetillo, O. A cell-based screen identifies ATR inhibitors with synthetic lethal properties for cancer-associated mutations. Nat Struct Mol Biol 2011, 18, (6), 721-7.

(9) Morandell, S.; Reinhardt, H. C.; Cannell, I. G.; Kim, J. S.; Ruf, D. M.; Mitra, T.; Couvillon, A. D.; Jacks, T.; Yaffe, M. B. A reversible gene-targeting strategy identifies synthetic lethal interactions between MK2 and p53 in the DNA damage response in vivo. Cell Rep 2013, 5, (4), 868-77.

(10) Reinhardt, H. C.; Aslanian, A. S.; Lees, J. A.; Yaffe, M. B. p53-deficient cells rely on ATM- and ATR-mediated checkpoint signaling through the p38MAPK/MK2 pathway for survival after DNA damage. Cancer Cell 2007, 11, (2), 175-89.

(11) Zitouni, S.; Nabais, C.; Jana, S. C.; Guerrero, A.; Bettencourt-Dias, M. Polo-like kinases: structural variations lead to multiple functions. Nat Rev Mol Cell Biol 2014, $15,(7), 433-52$.

(12) Sur, S.; Pagliarini, R.; Bunz, F.; Rago, C.; Diaz, L. A., Jr.; Kinzler, K. W.; Vogelstein, B.; Papadopoulos, N. A panel of isogenic human cancer cells suggests a therapeutic approach for cancers with inactivated p53. Proc Natl Acad Sci U S A 2009, 106, (10), 3964-9.

(13) Moser, R.; Xu, C.; Kao, M.; Annis, J.; Lerma, L. A.; Schaupp, C. M.; Gurley, K. 
E.; Jang, I. S.; Biktasova, A.; Yarbrough, W. G.; Margolin, A. A.; Grandori, C.; Kemp, C. J.; Mendez, E. Functional kinomics identifies candidate therapeutic targets in head and neck cancer. Clin Cancer Res 2014, 20, (16), 4274-88.

(14) Osman, A. A.; Monroe, M. M.; Ortega Alves, M. V.; Patel, A. A.; Katsonis, P.; Fitzgerald, A. L.; Neskey, D. M.; Frederick, M. J.; Woo, S. H.; Caulin, C.; Hsu, T. K.; McDonald, T. O.; Kimmel, M.; Meyn, R. E.; Lichtarge, O.; Myers, J. N. Wee-1 kinase inhibition overcomes cisplatin resistance associated with high-risk TP53 mutations in head and neck cancer through mitotic arrest followed by senescence. Mol Cancer Ther 2015, 14, (2), 608-19.

(15) Baldwin, A.; Grueneberg, D. A.; Hellner, K.; Sawyer, J.; Grace, M.; Li, W.; Harlow, E.; Munger, K. Kinase requirements in human cells: V. Synthetic lethal interactions between $\mathrm{p} 53$ and the protein kinases SGK2 and PAK3. Proc Natl Acad Sci U S A 2010, 107, (28), 12463-8.

(16) Jemaa, M.; Galluzzi, L.; Kepp, O.; Boileve, A.; Lissa, D.; Senovilla, L.; Harper, F.; Pierron, G.; Berardinelli, F.; Antoccia, A.; Castedo, M.; Vitale, I.; Kroemer, G. Preferential killing of p53-deficient cancer cells by reversine. Cell Cycle 2012, 11, (11), 2149-58.

(17) Gyorffy, B.; Bottai, G.; Lehmann-Che, J.; Keri, G.; Orfi, L.; Iwamoto, T.; Desmedt, C.; Bianchini, G.; Turner, N. C.; de The, H.; Andre, F.; Sotiriou, C.; Hortobagyi, G. N.; Di Leo, A.; Pusztai, L.; Santarpia, L. TP53 mutation-correlated genes predict the risk of tumor relapse and identify MPS1 as a potential therapeutic kinase in TP53-mutated breast cancers. Mol Oncol 2014, 8, (3), 508-19.

(18) Emerling, B. M.; Hurov, J. B.; Poulogiannis, G.; Tsukazawa, K. S.; Choo-Wing, R.; Wulf, G. M.; Bell, E. L.; Shim, H. S.; Lamia, K. A.; Rameh, L. E.; Bellinger, G.; Sasaki, A. T.; Asara, J. M.; Yuan, X.; Bullock, A.; Denicola, G. M.; Song, J.; Brown, V.; Signoretti, S.; Cantley, L. C. Depletion of a putatively druggable class of phosphatidylinositol kinases inhibits growth of p53-null tumors. Cell 2013, 155, (4), 844-57.

(19) Lokody, I. Signalling: a new target for p53-null tumours. Nat Rev Cancer 2014, $14,(1), 8-9$.

(20) Wang, L.; Xiong, H.; Wu, F.; Zhang, Y.; Wang, J.; Zhao, L.; Guo, X.; Chang, L. J.; Zhang, Y.; You, M. J.; Koochekpour, S.; Saleem, M.; Huang, H.; Lu, J.; Deng, Y. Hexokinase 2-mediated Warburg effect is required for PTEN- and p53-deficiency-driven prostate cancer growth. Cell Rep 2014, 8, (5), 1461-74.

(21) Chen, L.; Mayer, J. A.; Krisko, T. I.; Speers, C. W.; Wang, T.; Hilsenbeck, S. G.; Brown, P. H. Inhibition of the p38 kinase suppresses the proliferation of human ER-negative breast cancer cells. Cancer Res 2009, 69, (23), 8853-61.

(22) Zhao, J.; Zhao, D.; Poage, G. M.; Mazumdar, A.; Zhang, Y.; Hill, J. L.; Hartman, Z. C.; Savage, M. I.; Mills, G. B.; Brown, P. H. Death-associated protein kinase 1 promotes growth of p53-mutant cancers. J Clin Invest 2015, 125, (7), 2707-20.

(23) Menendez, D.; Lowe, J. M.; Snipe, J.; Resnick, M. A. Ligand dependent restoration of human TLR3 signaling and death in p53 mutant cells. Oncotarget 2016, 7, (38), 61630-61642.

(24) Haricharan, S.; Brown, P. TLR4 has a TP53-dependent dual role in regulating 
breast cancer cell growth. Proc Natl Acad Sci US A 2015, 112, (25), E3216-25.

(25) Parrales, A.; Iwakuma, T. Targeting Oncogenic Mutant p53 for Cancer Therapy. Front Oncol 2015, 5, 288.

(26) Weissmueller, S.; Manchado, E.; Saborowski, M.; Morris, J. P. t.; Wagenblast, E.; Davis, C. A.; Moon, S. H.; Pfister, N. T.; Tschaharganeh, D. F.; Kitzing, T.; Aust, D.; Markert, E. K.; Wu, J.; Grimmond, S. M.; Pilarsky, C.; Prives, C.; Biankin, A. V.; Lowe, S. W. Mutant p53 drives pancreatic cancer metastasis through cell-autonomous PDGF receptor beta signaling. Cell 2014, 157, (2), 382-394.

(27) Xiong, S.; Tu, H.; Kollareddy, M.; Pant, V.; Li, Q.; Zhang, Y.; Jackson, J. G.; Suh, Y. A.; Elizondo-Fraire, A. C.; Yang, P.; Chau, G.; Tashakori, M.; Wasylishen, A. R.; Ju, Z.; Solomon, H.; Rotter, V.; Liu, B.; El-Naggar, A. K.; Donehower, L. A.; Martinez, L. A.; Lozano, G. Pla2g16 phospholipase mediates gain-of-function activities of mutant p53. Proc Natl Acad Sci U S A 2014, 111, (30), 11145-50.

(28) Zhu, J.; Sammons, M. A.; Donahue, G.; Dou, Z.; Vedadi, M.; Getlik, M.; Barsyte-Lovejoy, D.; Al-awar, R.; Katona, B. W.; Shilatifard, A.; Huang, J.; Hua, X.; Arrowsmith, C. H.; Berger, S. L. Gain-of-function p53 mutants co-opt chromatin pathways to drive cancer growth. Nature 2015, 525, (7568), 206-11.

(29) Fiorini, C.; Cordani, M.; Padroni, C.; Blandino, G.; Di Agostino, S.; Donadelli, M. Mutant p53 stimulates chemoresistance of pancreatic adenocarcinoma cells to gemcitabine. Biochim Biophys Acta 2015, 1853, (1), 89-100.

(30) Li, D.; Marchenko, N. D.; Moll, U. M. SAHA shows preferential cytotoxicity in mutant p53 cancer cells by destabilizing mutant p53 through inhibition of the HDAC6-Hsp90 chaperone axis. Cell Death Differ 2011, 18, (12), 1904-13.

(31) Parrales, A.; Ranjan, A.; Iyer, S. V.; Padhye, S.; Weir, S. J.; Roy, A.; Iwakuma, T. DNAJA1 controls the fate of misfolded mutant p53 through the mevalonate pathway. Nat Cell Biol 2016, 18, (11), 1233-1243. 